[Re]Negotiating East and Southeast Asia 
SERIES EDITORS

Muthiah Alagappa

East-West Center

\author{
Amitav Acharya \\ University of Bristol \\ David Leheny \\ Princeton University
}

\author{
Alastair Iain Johnston \\ Harvard University \\ T. V. Paul \\ McGill University
}

Randall Schweller

The Ohio State University

\title{
INTERNATIONAL BOARD
}

Rajesh M. Basrur

Nanyang Technological University

Barry Buzan

London School of Economics

Thomas J. Christensen

Princeton University

Stephen P. Cohen

The Brookings Institution

Chu Yun-han

Academia Sinica

Rosemary Foot

University of Oxford

Aaron L. Friedberg

Princeton University

Sumit Ganguly

Indiana University, Bloomington

Avery Goldstein

University of Pennsylvania

Michael J. Green

Georgetown University; Center for

Stratetgic and International Studies

Stephan M. Haggard

University of California, San Diego

G. John Ikenberry

Princeton University

Takashi Inoguchi

Chuo University

Brian L. Job

University of British Columbia
Miles Kahler

University of California, San Diego

Peter J. Katzenstein

Cornell University

Khong Yuen Foong

University of Oxford

Byung-Kook Kim

Korea University

Michael Mastanduno

Dartmouth College

Mike Mochizuki

The George Washington University

Katherine H. S. Moon

Wellesley College

Qin Yaqing

China Foreign Affairs University

Christian Reus-Smit

Australian National University

Varun Sahni

Jawaharlal Nehru University

Etel Solingen

University of California, Irvine

Rizal Sukma

CSIS, Jakarta

Wu Xinbo

Fudan University 


\section{Studies in Asian Security}

A SERIES SPONSORED BY THE EAST-WEST CENTER

Muthiah Alagappa, Chief Editor

Distinguished Senior Fellow, East-West Center

The Studies in Asian Security book series promotes analysis, understanding, and explanation of the dynamics of domestic, transnational, and international security challenges in Asia. The peer-reviewed publications in the Series analyze contemporary security issues and problems to clarify debates in the scholarly community, provide new insights and perspectives, and identify new research and policy directions. Security is defined broadly to include the traditional political and military dimensions as well as nontraditional dimensions that affect the survival and well being of political communities. Asia, too, is defined broadly to include Northeast, Southeast, South, and Central Asia.

Designed to encourage original and rigorous scholarship, books in the Studies in Asian Security series seek to engage scholars, educators, and practitioners. Wide-ranging in scope and method, the Series is receptive to all paradigms, programs, and traditions and to an extensive array of methodologies now employed in the social sciences.

The East-West Center is an education and research organization established by the U.S. Congress in 1960 to strengthen relations and understanding among the peoples and nations of Asia, the Pacific, and the United States. Funding for the Center comes from the U.S. government, with additional support provided by private agencies, individuals, foundations, corporations, and the governments of the region. 



\section{[Re]Negotiating East and Southeast Asia}

REGION, REGIONALISM, AND THE ASSOCIATION

OF SOUTHEAST ASIAN NATIONS

Alice D. Ba 
Stanford University Press

Stanford, California

(C) 2009 by the Board of Trustees of the Leland Stanford Junior University. All rights reserved.

No part of this book may be reproduced or transmitted in any form or by any means, electronic or mechanical, including photocopying and recording, or in any information storage or retrieval system without the prior written permission of Stanford University Press.

Printed in the United States of America on acid-free, archival-quality paper

Library of Congress Cataloging-in-Publication Data

Ba, Alice D.

(Re)negotiating East and Southeast Asia : region, regionalism, and the Association of Southeast Asian Nations / Alice D. Ba.

p. cm. - (Studies in Asian security)

Includes bibliographical references and index.

ISBN 978-0-8047-6069-0 (cloth : alk. paper)—ISBN 978-0-8047-6070-6

(pbk. : alk. paper)

I. Southeast Asia-Foreign relations. 2. Southeast Asia-Politics and government-I945- 3. ASEAN. 4. Regionalism-Southeast Asia. 5. RegionalismEast Asia. 6. Southeast Asia-Foreign relations-East Asia. 7. East AsiaForeign relations-Southeast Asia. I. Title. II. Title: Renegotiating East and Southeast Asia. III. Series: Studies in Asian security.

DS $525.8 . \mathrm{B}_{33} 2009$

34I.24'73- dc22

2008047523

Typeset by Thompson Type in 10.5/13.5 Bembo 
Just as none of us is outside or beyond geography, none of us is completely free from the struggle over geography. That struggle is complex and interesting because it is not only about soldiers and cannons but also about ideas, about forms, about images and imaginings.

Edward Said Culture and Imperialism (1993) 
